\title{
MUKOSA OLFAKTORIA
}

\author{
Sunny Wangko \\ Bagaian Anatomi-Histologi Fakultas Kedokteran Universitas Sam Ratulangi Manado \\ Email: sunnywangko@yahoo.com
}

Kavum nasi merupakan sepasang ruangan yang dipisahkan oleh septum terdiri dari tulang rawan dan tulang. Ruangan-ruangan tersebut berbentuk memanjang dengan dasar melebar, terletak pada palatum durum dan palatum mole. Bagaian apeks menyempit ke arah fosa kranialis anterior. Rangka kavum nasi dibentuk oleh tulang dan tulang rawan yang terletak di bagian tengah tengkorak, kecuali sebagian kecil di sebelah anterior yaitu hidung bagian luar.

Ruangan kavum nasi terdiri atas tiga regio: vestibulum nasi, regio respiratoria dan regio olfaktoria. Vestibulum nasi adalah bagian kavum nasi yang berdilatasi tepat di bagian dalam lubang hidung dan dilapisi oleh kulit. Regio respiratoria merupakan bagian terbesar kavum nasi (sekitar 2/3 bagian sebelah inferior) dan dilapisi oleh epitel respiratoria. Regio olfaktoria terletak di apeks (1/3 bagian atas) kavum nasi dan dilapisi oleh mukosa olfaktoria yang merupakan indra penghidu.

\section{LETAK DAN STRUKTUR UMUM MUKOSA OLFAKTORIA}

Mukosa olfaktoria terletak pada bagian puncak setiap ruangan kavum nasi, berbatasan dengan dinding lateral dan medialnya (Gambar 1). Regio ini dilapisi oleh mukosa olfaktoria yang dalam keadaan hidup berwarna coklat kekuningan (berbeda dengan sekitarnya yang berwarna merah jambu) oleh karena kandungan pigmen dalam epitel olfaktoria dan kelenjar olfaktoria. Pada manusia luas permukaan total dari mukosa olfaktoria sekitar $10 \mathrm{~cm}^{2}$. Pada hewan dengan penciuman yang tajam, luas mukosa olfaktoria jauh lebih besar; sebagai contoh: pada jenis anjing tertentu, luas mukosa olfaktoria $>150 \mathrm{~cm}^{2}$.

Lamina propria mukosa olfaktoria berhubungan langsung dengan periosteum tulang yang berlekatan. Jaringan ikatnya mengandung banyak pembuluh darah dan limf, nervus olfaktoria tak bermielin, dan kelenjar olfaktoria (Gambar 2).
Epitel olfaktoria merupakan epitel bertingkat dengan beberapa jenis sel, yaitu: sel reseptor olfaktoria, sel sustentakular (penyokong), sel basal, dan sel sikat (brush cells); tetapi tidak mengandung sel goblet. Sel reseptor olfaktoria merupakan neuron bipolar yang merentang seluruh ketebalan epitel dan masuk ke dalam sistem saraf pusat. Sel sustentakular berbentuk torak. Seperti halnya sel-sel neuroglia, sel-sel ini menyokong sel reseptor olfaktoria baik secara mekanis maupun metabolik. Sel-sel ini menyintesis dan menyekresi odorantbinding proteins (OBPs). Sel basal ialah sel stem yang merupakan asal sel-sel reseptor olfaktoria dan sel sustentakular. Sel sikat merupakan jenis sel yang sama dengan epitel respiratoria (Gambar 1, 2).

\section{Sel reseptor olfaktoria}

Sel reseptor olfaktoria merupakan sel neuron bipolar dengan proyeksi apikal berbentuk silia. 